\title{
Erratum to: Oncolytic virus efficiency inhibited growth of tumour cells with multiple drug resistant phenotype in vivo and in vitro
}

Elena P. Goncharova', Julia S. Ruzhenkova' ${ }^{1}$ Ivan S. Petrov ${ }^{1,3}$, Sergey N. Shchelkunov² and Marina A. Zenkova ${ }^{\text {* }}$

\section{Erratum to: J Transl Med (2016) 14:241 DOI 10.1186/s12967-016-1002-x}

Unfortunately, the original version of this article [1] contained an error. Figures 2 and 7 were the incorrect versions. They have been corrected in the original article and are also included correctly in this erratum.
*Correspondence: marzen@niboch.nsc.ru

'Institute of Chemical Biology and Fundamental Medicine SB RAS, 8, Lavrentiev Ave., Novosibirsk 630090, Russian Federation

Full list of author information is available at the end of the article
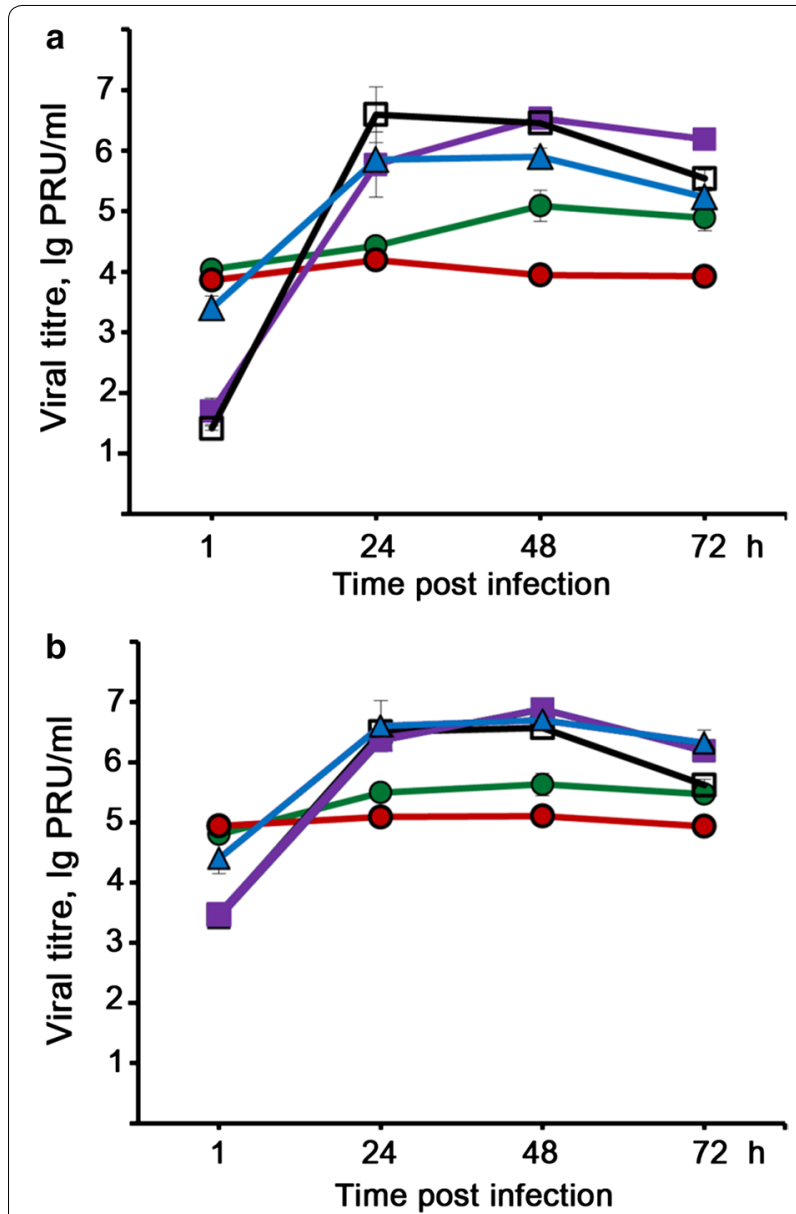

Fig. 2 Development of LIVP-GFP infection in various tumour cells. Development of LIVP-GFP infection in RLS (green circles), RLS-40 (red circles), KB-3-1 (violet squares), KB-8-5 (black line with open squares) and melanoma B-16 (blue triangles) tumour cells at $\mathrm{MOI}$ of 1 (a) and $\mathrm{MOI}$ of 10 (b). Cells were incubated with virus for $1 \mathrm{~h}$, washed with PBS and incubated up to the analysis in IMDM supplemented with $2 \%$ FBS. Viral titre was measured by PFU assay. Data of three independent experiments are presented

\section{Biomed Central}

(c) 2016 The Author(s). This article is distributed under the terms of the Creative Commons Attribution 4.0 International License (http://creativecommons.org/licenses/by/4.0/), which permits unrestricted use, distribution, and reproduction in any medium, provided you give appropriate credit to the original author(s) and the source, provide a link to the Creative Commons license, and indicate if changes were made. The Creative Commons Public Domain Dedication waiver (http://creativecommons.org/ publicdomain/zero/1.0/) applies to the data made available in this article, unless otherwise stated. 

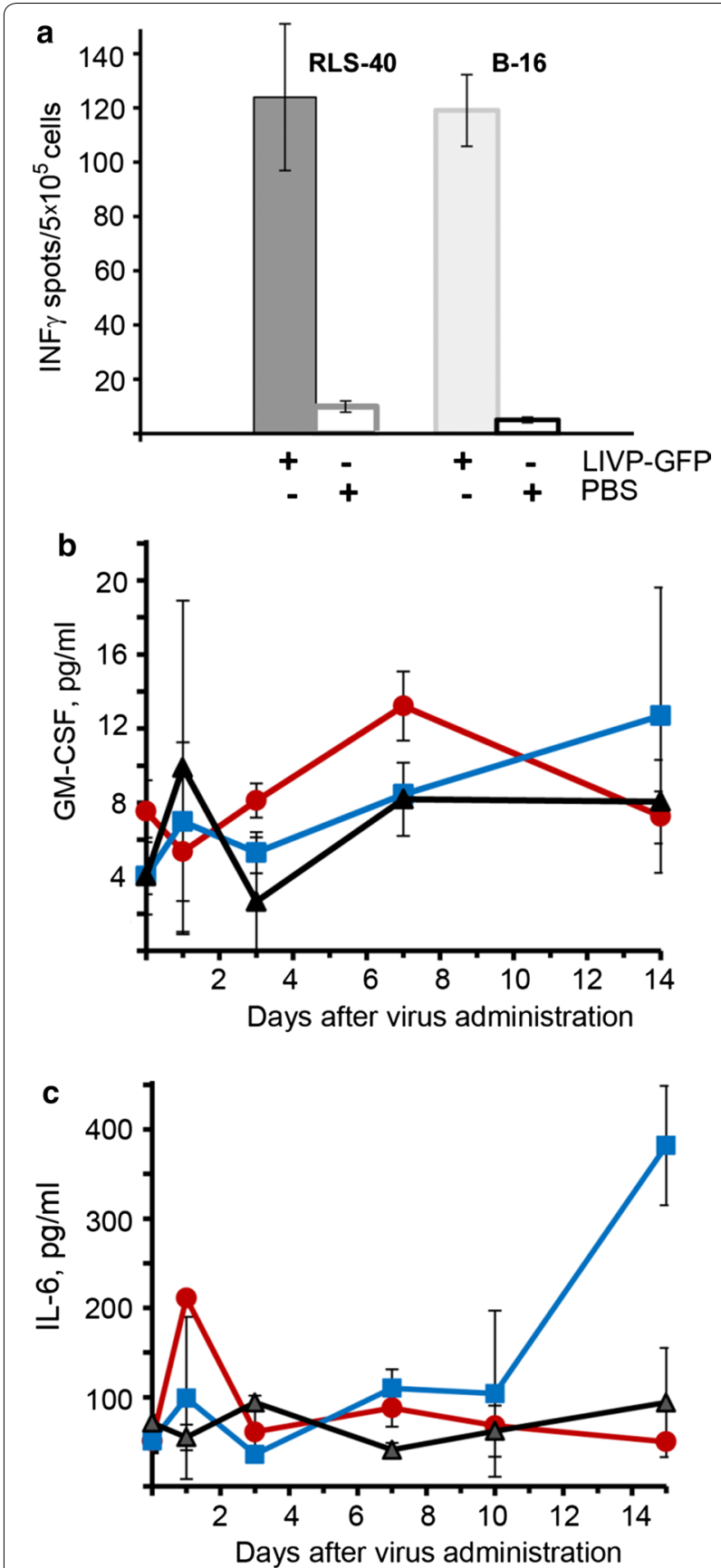

Fig. 7 Effect of LIVP-GFP treatment on the immune responses of tumour-bearing mice. a Summary data showing a significant increase of the number of IFN- $y$-ransecreting splenocytes in LIVP-GFP-treated mice $(n=6)$ with RLS-40 or with melanoma B-16 tumours. Comparison of immune-related proteins GMC-SF (b) and IL-6 (c) in the blood serum of RLS-40 bearing mice during the treatment with LIVP-GFP (the experimental scheme was shown in Fig. 5a): red circles and blue squares for RLS-40 bearing mice treated with LIVP-GFP and PBS, respectively; black triangles healthy mice receiving PBS. The levels of cytokines in the blood serum were measured by ELISA. For each day, the value of mean \pm SEM is shown

\section{Author details}

${ }^{1}$ Institute of Chemical Biology and Fundamental Medicine SB RAS, 8 ,

Lavrentiev Ave., Novosibirsk 630090, Russian Federation. ${ }^{2}$ Institute of Cytology and Genetics SB RAS, Novosibirsk, Russian Federation. ${ }^{3}$ Department of Biochemistry, Biocenter, University of Wuerzburg, Am Hubland, 97074 Würzburg, Germany.

The online version of the original article can be found under doi:10.1186/s12967-016-1002-x.

Published online: 27 September 2016

\section{Reference}

1. Goncharova EP, Ruzhenkova JS, Petrov IS, Shchelkunov SN, Zenkova MA. J Transl Med. 2016;14:241. doi:10.1186/s12967-016-1002-X. 